\title{
Demographic Characteristics and the Attraction to Facilities in Shopping Malls: A Case of Ibadan, Nigeria
}

Chukwuemeka Iroham, Department of Estate Management, College of Science and Technology, Covenant University, Ota.

Olajumoke Akinwale, Department of Estate Management, College of Science and Technology, Covenant University, Ota.

Nkolika Peter*, Department of Estate Management, College of Science and Technology, Covenant University, Ota.

E-mail:nkolika.peter@covenantuniversity.edu.ng

Abiodun Oni, Department of Estate Management, College of Science and Technology, Covenant University, Ota.

Hilary Okagbue, Department of Mathematics, College of Science and Technology, Covenant University, Ota.

Moses Emetere, Department of Physics, College of Science and Technology, Covenant University, Ota.

Department of Mechanical Engineering Science, University of Johannesburg, APK, South Africa.

Mayowa Ajibola, Department of Estate Management, College of Science and Technology, Covenant University, Ota.

\begin{abstract}
The paper aimed at determining the demographic features of customers in shopping mall that are prone to be attracted by facilities in the malls. The five shopping malls in Ibadan, Nigeria were studied. The research which is a cross-sectional survey adopted the intercept approach to customers resulting to the distribution of 143, $126,127,145$ and 126 shoppers of the respective malls. A response rate of over $80 \%$ was attained and data collected was analysed using the weighted mean and confirmation test on the significance of result was achieved using the Chi-Square test of significance at $95 \%$ confidence level. Out of the four demographic features studied, it was discovered that only gender had significant result as females were more likely to be attracted to facilities provided in shopping malls than their male counterpart. The researchers hereby advocated gender sensitivity in erecting facilities in malls as that might enhance patronage.
\end{abstract}

Keywords--- Attraction, Demographic Characteristics, Facilities, Shopping Mall, Nigeria.

\section{Introduction}

Demography can be defined as the study of the characteristics of a population. It brings about a mathematical description of how the said characteristics varied over time. Amongst issues included in demography are statistical factors that influence population growth or decline, population size, density, age structure, fecundity, mortality, sex, income level and status amongst others (Dodge, 2006). Ever since, demography has been described to affect the rate of growth of output and the pattern of income distribution (Jones, 1976). This was buttressed by the Education Services of the Commission of the European Community (1981) that described demographic studies to be relevant on the development of national economics, educational system, labour market and infact the whole social system. That could explain why the import of demography has sprawled literature in various fields. This is seen but not limited to areas such as health care (Guile, Graham, and Jachmann, 2018); banking (Nayyab, Sehr, Adnan, and Ali, 2011; al Afeef, Singh, and Ahmad, 2012; Berlemann, Oestmann, and Thum, 2014; Doerr, and Kabas, 2019); sports (Nelson, Howe, Nguyen, Leung, Trout,Seibel, Baxter,........, and Ho, 2006; Eime, Harvey, Charity, and Nelson, 2018); education (VanderStel, 2014); professional practice (Solomon, 2007; Ngangu, 2016); hospitality business (Wong, Siu, and Tsang, 1999) and even recreation (Bustam, Thapa, and Buta, 2011; Biernat, and Tomaszewski, 2011; Child, Kaczynski, Sharpe, Wilcox, Schoffman, Forthofer, Mowen, and Barr-Anderson, 2015) just to mention a few.

Demographic studies can be said to have no limits while relating it to any given concept or phenomenon. Lutz, Cuaresma, Kebede, Prskawetz, Sanderson, and Striessnig, (2019) concluded that true human capital dividend can be gotten from a true demographic dividend and as such global population policies should henceforth focus on strengthening the human resource base for sustainable development. One visible way by which this can be effectively done is the creation of jobs in a world where automation and digitalisation is increasing notwithstanding the surge in population growth (Bloom, McKenna, and Prettner, 2018). The linkage between demography and virtually every concept tends to study how the various make up in the population will react to any given issue. 
Shopping malls are not left out because persons have to patronize this modern retail stores. Shopping malls particularly in the developing economy have been colloquially ascribed to various types of shopping edifice. However, the definition proclaimed by Urban Land Institute's (ULI) as cited in Reikili, (2012) will suffice: "A group of architecturally unified commercial establishments built on a site that is planned, developed, owned, and managed as an operating unit related by its location, size, and type of shops to the trade area that it serves.

The unit provides on-site parking in definite relationship to the types and total size of the stores." One predominant feature of shopping malls is their sizes having a minimum average land area of about 400, 000 square feet or 37, 161. 216M2. In Nigeria, when the erection of shopping malls commenced in 2005 with the Palms shopping mall research has been carried out in relation to shopping malls on various aspects. As expected demographic characteristics were also pinpointed in the study of shopping malls. Carpenter (2008) studied the influence of demographic characteristics in determining patronage of shopping malls amongst shoppers in the US. Demographic characteristics such as age, culture background, gender, academic qualification, marital status, size of family, income level and visitation rate to the malls were revealed to have remarkable influence on the mall's patronage. Sohali, 2015) also discovered that demography is the principal influence on patronage of shoppers. For instance it was discovered that shoppers within the age bracket of 18 and 24 years had the highest patronage of malls. Educated shoppers and shoppers' high income level have most influence on patronage on shopping mall even the female shoppers exhibited more patronage of shopping malls compared to their male counterparts. A finding that has also been corroborated by a later research (Abrudan, 2016). However, though demography has been associated with shopping malls, there are no record of research in relating demography characteristics with inherent facilities in the mall. Anderson (1973) has long associated demography with facilities even though it was a study on the health sector where it was established that demographic characteristics, organisation of health services, ecological factors and social psychological factors influence the utilization of health services. In fact subsequent research on demographic characteristics and facilities in the health sector were even confined to the new-borns (Fotso, Bellhouse, Vesel, and Jezman, 2015).

Facilities in shopping malls are not only capital intensive but gives the mall the decorative ambiance and its functionalities. This is believed to cater for entertainment, diversity of categories, convenience of customers and physical design of the building which according to Joshi and Gupta, (2017) if absent will result to about $90 \%$ of the loss of customers. This happens to be the crux of this present study to discover how these facilities are being appreciated based on the varied demographic characteristics of the customers that visit the malls. This is justified based on the declaration that a vital consideration in the facility decision necessitates matching the need of the population with services required (Graham, 2018). Emphasis is placed on the five shopping malls in Ibadan, Nigeria that meet the proclaimed definition of malls. The malls are Cocoa Mall described as Mall A subsequently in this study; Heritage Mall described as Mall B subsequently in this study and Jericho Mall described as Mall C subsequently in this study. Others are Palms Mall and Ventura Mall respectively described as Mall D and Mall E in the study. This study will also bring about a shift of research to other cities in the country apart from Lagos, Abuja and Port-Harcourt considered as the three most buoyant property markets in the country (Iroham, Durodola, Oluwatobi and Peter, 2015).

\section{Attraction to Shopping Malls}

Traditional markets these days seems to be gradually phasing out for the more modern outfits of which shopping mall forms part. This has attracted all and sundry in form of patronage to shopping malls. The image of shopping mall has been seen as a pull factor in attracting shoppers. This is the findings from Hassan, Muhammad and Bakar (2010) on using Darden's patronage model on behavious of consumers. Analysis from regression of data gotten from 115 respondents issued questionnaires revealed that apart from the image of the mall, the lifestyle of the shoppers and shoppers' orientation were very major determination in attracting customers to the mall. Location has been studied with respect to its influence on attracting customers to the mall. Mokgabudi (2011) tried to discover if distance of the mall will be a hindering factor compared to settling for local stores that have much proximity. The use of qualitative and quantitative approach with semi-structured interview with tenants and copies of questionnaires distribution to shoppers revealed that the distance of shopping malls was not a hindering factor. However, the study also discovered that quality products, lower prices, variety of goods and the social and psychological satisfaction were also pull factors to the mall.

Malik and Ali Syed (2013) carried out a survey amongst males and females customers in Delhi and National Capital Region. The researchers used convenience sampling technique and intercept survey method to distribute questionnaires to shoppers. Responses were required on variables such as store image and shoppers motive as 
determinants of the usage of malls. These variables were further subdivided into subdivisions like retail merchandise, atmospheric and retail communication, shopping convenience, utilitarian socialization and gratification as factors that influence shoppers to malls. The analysis of the 1, 200 copies of questionnaires retrieved indicated variables such as merchandise, convenience, shopping mall atmosphere and communication were ranked more as pull factors to malls. The result gave more credence to the image of shopping malls as the triggering factor that influences shoppers. A similar result was derived from a research carried out in Southern Gauteng, South-Africa where it was confirmed that shopping mall image has a triggering effect on customers (Dubihlela, 2014). Hira and Mehvish (2012) not only discovered that image of shopping malls had triggering impart on drawing customers to the mall, the environment and the convenience of the shopping malls also had substantial influence. The image of the malls was also attributed to have ripple effect on the various retail outlets in the malls. This was findings from North-America through self-congruity image transfer from the patronage of malls to its stores (Kedhi, Zourrig, and Park, 2017). There is also a related result from a much earlier research where it was also discovered that the pull by inherent stores also results to the much patronage of the malls itself (Rabbanee, Ramaseshan, Wu, and Vinden, 2012).

The attractive force to shopping malls in India were discovered to be quality and assorted goods, new product, variety of product and easy location on the shelf, safety as well as security. This was a result from data gotten from 100 shoppers that were placed on a five-point likert scale and analysed using the Chi-square test on SPSS Software package version 16. The attraction to shopping mall in Nigeria was studied through factors that determine mall patronage frequency in the country. The authors used self-administered questionnaires to retrieve data from 1537 shoppers of not less than 18 years in about six (6) malls using intercept approach. The use of structural equation modelling technique was utilized to assess the hypothesized causal relationship through the use of SmartPLS 2.0 software. The result indicated that shoppers' ethnicity background and their age have interaction effect (Idoko, Ukenna, and Obeta, 2019). Another article in Nigeria that tried to study factors that attract customers to shopping mall was that carried out in Enugu by Okoro, Okolo and Mmamel (2019). The authors tested variables such as distance, convenience, socialization, exploration, and customer's service. The research was a survey involving the distribution of 596 well-structured questionnaires to customers above the age of 18 years. Five hypotheses were tested using Structural Equation Modeling run on AMOS version 25.0 with maximum likelihood estimation. It was revealed that distance and customer service does not have a significant influence in attracting customers to shopping mall while the other three variables, convenience, socialization and exploration had remarkable significant influence in attracting customers to shopping malls.

Notwithstanding that customers have one form of attraction to malls or the other, it has been recorded that about $90 \%$ of the time, malls have failed to attract their targeted customers (Joshi and Gupta, 2017). This according to the authors have been attributed to the malls not meeting needs of customers in the area of entertainment, diversity of categories, convenience of customers and physical design of the building. There is therefore a need to avoid these as attrition has become a topical issue in modern research (Peter, Ayedun and Iroham, 2018). This study hereby envisages that a particular feature of the mall which when properly harnessed could be able to provide these will be its facilities. Not just because of the huge cost which goes for its installation but for the decorative ambiance it gives to the mall.

\section{Facilities and Attraction to Shopping Malls}

The review of literature on facilities in shopping malls both in the internal and external mall services revealed the import of facilities in malls (Juhari, Ali and Khair, 2012). A study involving 457 shoppers in 7 shopping malls in Durban South Africa revealed that parking lots, food courts, banking facilities, child care facility, entertainment, as well as facilities that cater for the incapacitated and those who are feeble do attract shoppers to the malls (Poolvalingam and Docrat, 2011).

In India it was discovered that facilities do not necessarily attract shoppers to the mall. Facilities such as food court, cinema halls, lightening, music, design and entertainment facility were studied though its attrition to customers were insignificant (Khare (2012). Still in India, Mittal and Jhamb (2016) carried out a research to determine the variables that attract shoppers to the mall.

The study which centered on two prominent malls in the country tested four identified factors. One of such factors was facilities while others included marketing, assortment, and convenience. 500 shoppers made up the respondents for the study who were approached using intercept approach while the four variables were broken down into 16 sub-variables. The result from factor analysis revealed that facilities does not have a significant attraction to customers that come to the mall. The only variable that had remarkable influence on the customers was assortment. 
However, a later research carried out in India by Gupta and Gupta, (2017) revealed that Comfortable sitting area, space in the mall, mall atmosphere and décor, maintenance and cleanliness in the mall, and good customer service do attract shopper to malls. This result is an aftermath of a research conducted on 90 shoppers in three malls. The import of these facilities can also be gathered from subsequent findings of the authors indicating the attraction of shoppers to more enhanced property management than product pricing.

A more extensive study involving more customers in India was carried out. The research which was conducted in Mumbai on 665 customers across five shopping malls discovered that 222 variables using the neural network model had significant attraction to customers. Some of the variables which also include facilities provided in the mall are availability of seats in the mall, provision of parking lots, convenience and security provided (Prashar, Singh, Parsad and Vijay, 2017). Research on the attraction of facilities to malls has also been carried out in Pakistani. The research which was confined to two facilities, kids play center, and parking lot was studied together with location of the malls. The study which involved 322 customers of the malls revealed that the three variables studied had influence on attracting customers to the shopping malls (Bhatti, and Latif, 2014).

In Sydney Australia, the influence of a particular facility and its attraction to shopping malls was the focus of the research carried out by Bailey (2015). The researcher studied entertainment centres and how they have been able to attract customers to malls. It was discovered that entertainment centres such as cinema complexes strategically located within a mall, adjacent to a mall, or very close to a mall had a remarkable pull of customers to the mall. In essence it was discovered that some customers who came to the mall would have not gone there if not for the cinema that brought them to that vicinity in the first instance. According to Monisha, Divyalakshmi, and Dhivyaa (2019) apart from the existence of a favourable location, understanding of consumer behavior, tenant mix and concurrently shopping centre, the presence of a parking lot, clean ambiance, elevators, spacious dining areas and recreational facilities will attract customers to malls. The authors however advised that managers of any given mall must have the ability to anticipate and align with changing customer needs so as to ensure that enough excitement that will attract the customers does exist.

\section{III.Data and Methods}

The population of this study comprises the customers who come to shop at the five (5) identified shopping malls in Ibadan, Nigeria. The population for this study are the identified numbers of shopping malls in Ibadan which enables the researchers to locate the shoppers that form the population of this study. From pre-research investigation, a total of five (5) malls are evident in Ibadan. These malls for the sake of convenience will be described as Mall A for Cocoa Mall;Mall B will be assigned to Heritage Mall; Mall C will be ascribed to Jericho Mall; Palms Mall and Ventura Mall will be given the appellation of Mall D and Mall E respectively. The study is a cross-sectional survey that involved the distribution of questionnaires to customers of the five identified shopping malls in Ibadan, Nigeria. The use of purposive sampling to identified adults who are presumed to be at least 18 years was adopted thereafter a random sampling technique using the intercept survey approach was utilized. This resulted in the distribution of 143, 126, 127, 145 and 126 questionnaires to shoppers of Cocoa Mall, Heritage Mall, Jericho Mall, Palms Mall and Ventura Mall respectively. The questionnaire was structured into two major segment with the first dealing with the demographic characteristics of the customers in terms of gender, age, marital status, and income level. The second segment of the questionnaire was centred on the facilities provided in the mall and how it has aided in attracting shoppers to the mall. From a pre-research investigation it was discovered that certain principal facilities are common to the various malls being studied. The facilities are recreation and entertainment facilities, sufficient parking lot, children play centre, crèche facility, restroom facility, sitting area, free phone charging, elevator/escalator, availability of bank, automated teller machine/point of sale system; and Medical Facility. Further investigations from the pre-research study confirmed the affirmation of customers on the perfect working condition of the facilities in the malls. Data collected was placed on a linkert scale for ease of analysis to arrive at the weighted mean of the responses there after a measure of relationship using the spearman rank order correlation technique was adopted to discover the level of relationship between the given variables if any.

\section{Results and Discussion}

With the aid of field assistants a total of five hundred and fifty three (553) questionnaires were distributed to the customers of the various malls.

A total of four hundred and forty four (444) questionnaires were retrieved representing a response rate of over $80 \%$. Table 1 gives the graphic details of the response rate 
Table 1: Response Rate of Respondents

\begin{tabular}{|l|l|l|l|}
\hline Shopping Mall & No. of Questionnaires Administered & $\begin{array}{l}\text { No. of Questionnaires } \\
\text { Retrieved }\end{array}$ & $\begin{array}{l}\text { Percentage of Retrieved } \\
\text { Questionnaires (\%) }\end{array}$ \\
\hline A & 114 & 87 & 76.3 \\
\hline B & 103 & 97 & 94.2 \\
\hline C & 104 & 83 & 79.8 \\
\hline D & 113 & 92 & 81.4 \\
\hline E & 119 & 85 & 71.4 \\
\hline TOTAL & $\mathbf{5 5 3}$ & $\mathbf{4 4 4}$ & $\mathbf{8 0 . 3}$ \\
\hline
\end{tabular}

Gender on Attraction to Facilities

There was a question on the attraction to both the male and female customers of the facilities provided in the mall influencing their visitation to the malls. The responses are as presented in Table 2

Table 2: Gender Attraction to Facilities of Malls

\begin{tabular}{|l|l|l|l|l|l|l|l|l|}
\hline SM & Gender & $\begin{array}{l}\text { No. of } \\
\text { respondents }\end{array}$ & $\begin{array}{l}\text { Well } \\
\text { attracted }\end{array}$ & attracted & indifferent & $\begin{array}{l}\text { Not } \\
\text { attracted }\end{array}$ & $\begin{array}{l}\text { No } \\
\text { response }\end{array}$ & $\begin{array}{l}\text { Weighted } \\
\text { Mean }\end{array}$ \\
\hline \multirow{2}{*}{$\mathrm{A}$} & Male & 28 & 6 & 8 & 5 & 6 & 3 & 3.28 \\
\cline { 2 - 9 } & Female & 59 & 25 & 13 & 2 & 8 & 11 & 3.56 \\
\hline \multirow{2}{*}{$\mathrm{B}$} & Male & 56 & 10 & 14 & 7 & 12 & 13 & 2.93 \\
\cline { 2 - 9 } & Female & 41 & 18 & 11 & 9 & 1 & 2 & 4.02 \\
\hline $\mathrm{C}$ & Male & 42 & 11 & 17 & 5 & 3 & 6 & 3.57 \\
\cline { 2 - 8 } & Female & 41 & 16 & 9 & 12 & 4 & 0 & 3.90 \\
\hline \multirow{2}{*}{$\mathrm{D}$} & Male & 40 & 13 & 6 & 8 & 10 & 3 & 3.40 \\
\cline { 2 - 8 } & Female & 52 & 29 & 12 & 6 & 1 & 4 & 4.17 \\
\hline E & Male & 39 & 14 & 7 & 10 & 2 & 6 & 3.54 \\
\hline & Female & 46 & 20 & 13 & 8 & 4 & 1 & 4.02 \\
\hline Total & Male & $\mathbf{2 0 5}$ & $\mathbf{5 4}$ & $\mathbf{5 2}$ & $\mathbf{3 5}$ & $\mathbf{3 3}$ & $\mathbf{3 1}$ & $\mathbf{3 . 3 2}$ \\
\hline & Female & $\mathbf{2 3 9}$ & $\mathbf{1 0 8}$ & $\mathbf{5 8}$ & $\mathbf{3 7}$ & $\mathbf{1 8}$ & $\mathbf{1 8}$ & $\mathbf{3 . 9 2}$ \\
\hline
\end{tabular}

From Table 1, it can be deduced that both gender are attracted by the facilities in the malls having exceeded a weighted mean of 2.5. However, a look at the Table also depicts that females are more attracted to facilities of shopping malls compared to their male counterparts. This is evident from the higher weighted mean recorded for all the shopping malls and even the collective study of the malls.

In order to test for any significance in the result, the Chi-Square test of significance at the $95 \%$ level of confidence was employed. Table 3 gives graphic details

Table 3: Chi-Square Table of Significance on Gender

\begin{tabular}{|l|l|l|l|l|l|l|}
\hline Gender & $\begin{array}{l}\text { Well } \\
\text { attracted }\end{array}$ & attracted & indifferent & $\begin{array}{l}\text { Not } \\
\text { attracted }\end{array}$ & $\begin{array}{l}\text { No } \\
\text { response }\end{array}$ & $\begin{array}{l}\text { Row sub- } \\
\text { total }\end{array}$ \\
\hline Male & $54(74.80)$ & $52(50.79)$ & $35(33.24)$ & $33(23.55)$ & $31(22.62)$ & $\mathbf{2 0 5}$ \\
\hline Female & $108(87.20)$ & $58(59.21)$ & $37(38.76)$ & $18(27.45)$ & $18(26.38)$ & $\mathbf{2 3 9}$ \\
\hline $\begin{array}{l}\text { Column } \\
\text { sub-total }\end{array}$ & $\mathbf{1 6 2}$ & $\mathbf{1 1 0}$ & $\mathbf{7 2}$ & $\mathbf{5 1}$ & $\mathbf{4 9}$ & $\mathbf{4 4 4}$ \\
\hline
\end{tabular}

The Chi-Square formular $=\sum(\mathrm{O}-\mathrm{E}) 2 / \mathrm{E}$; while the Degree of Freedom $(\mathrm{df})=($ Row minus 1$)($ Column minus 1$)$

Expected frequencies are those put in the bracket in each cell derived by the product of the subtotal of column and that of the subtotal of row divided by the grand total. The Chi-Square test for each of the cells is deduced as follows: $5.7840 ; 0.0288 ; 0.0932 ; 3.7920 ; 3.1045 ; 4.9615 ; 0.0247 ; 0.0799 ; 3.2533 ; 2.6620$.

This gives $\sum$ of 23.7839. A (df) of 4 on the statistical table gives a value of 9.488. Since Cal $\vee 2>$ Tab Cal $\vee 2$, the decision rule stipulates significance in the result derived earlier. Hence, females are more attracted to the facilities in shopping malls than their male counterparts.

Age on Attraction to Facilities

Question on the attraction of facilities to the malls was also asked with respect to the various ages of the respondents. Details are as presented in Table 4 
Table 4: Age attraction to Facilities of Malls

\begin{tabular}{|c|c|c|c|c|c|c|c|c|}
\hline SM & Age & $\begin{array}{l}\text { No. of } \\
\text { respondents }\end{array}$ & $\begin{array}{l}\text { Well } \\
\text { attracted }\end{array}$ & attracted & indifferent & $\begin{array}{l}\text { Not } \\
\text { attracted }\end{array}$ & $\begin{array}{l}\text { No } \\
\text { response }\end{array}$ & $\begin{array}{l}\text { Weighted } \\
\text { Mean }\end{array}$ \\
\hline \multirow[t]{4}{*}{ A } & $<21$ years & 16 & 8 & 3 & 2 & 1 & 2 & 4.13 \\
\hline & $21-30 y r s$ & 37 & 19 & 7 & 6 & 4 & 1 & 4.05 \\
\hline & $31-40 y r s$ & 26 & 15 & 6 & 1 & 0 & 4 & 4.08 \\
\hline & $>40 \mathrm{yrs}$ & 8 & 4 & 1 & 2 & 1 & 0 & 4.00 \\
\hline \multirow[t]{4}{*}{ B } & $<21$ years & 25 & 11 & 6 & 4 & 2 & 2 & 3.88 \\
\hline & $21-30 y r s$ & 40 & 16 & 12 & 7 & 1 & 4 & 3.88 \\
\hline & $31-40 y r s$ & 22 & 10 & 8 & 1 & 2 & 1 & 3.64 \\
\hline & $>40 \mathrm{yrs}$ & 10 & 6 & 2 & 1 & 1 & 0 & 4.30 \\
\hline \multirow[t]{4}{*}{$\mathrm{C}$} & $<21$ years & 17 & 7 & 6 & 2 & 1 & 1 & 4.00 \\
\hline & $21-30 y r s$ & 28 & 12 & 4 & 9 & 0 & 3 & 3.79 \\
\hline & $31-40 y r s$ & 24 & 13 & 6 & 1 & 2 & 2 & 4.08 \\
\hline & $>40 \mathrm{yrs}$ & 14 & 8 & 1 & 1 & 1 & 3 & 3.71 \\
\hline \multirow[t]{4}{*}{ D } & $<21$ years & 21 & 14 & 2 & 4 & 0 & 1 & 4.33 \\
\hline & $21-30 y r s$ & 36 & 17 & 8 & 6 & 1 & 3 & 3.86 \\
\hline & 31-40yrs & 26 & 12 & 6 & 4 & 4 & 0 & 4.00 \\
\hline & $>40 \mathrm{yrs}$ & 9 & 4 & 1 & 2 & 1 & 1 & 3.67 \\
\hline \multirow[t]{4}{*}{$\mathrm{E}$} & $<21$ years & 18 & 6 & 3 & 4 & 4 & 1 & 3.50 \\
\hline & $21-30 y r s$ & 41 & 19 & 13 & 3 & 1 & 5 & 3.98 \\
\hline & $31-40 y r s$ & 17 & 8 & 4 & 3 & 0 & 2 & 3.94 \\
\hline & $>40 \mathrm{yrs}$ & 9 & 2 & 5 & 0 & 1 & 1 & 3.67 \\
\hline \multirow[t]{4}{*}{ Total } & $<21$ years & 97 & 46 & 20 & 16 & 8 & 7 & 3.92 \\
\hline & 21-30yrs & 182 & 83 & 44 & 31 & 7 & 17 & 3.93 \\
\hline & 31-40yrs & 115 & 58 & 30 & 10 & 8 & 9 & 4.04 \\
\hline & $>40 \mathrm{yrs}$ & 50 & 24 & 10 & 6 & 5 & 5 & 3.86 \\
\hline
\end{tabular}

From Table 4, it can be deduced there are no specific age that is mostly attracted to the facilities in the various malls. All age ranges are quite having exceeded a weighted mean of 2.5. For the individual malls, For Mall A customers below the age of 21 years are mostly attracted to the mall (4.13) while customers above 40 years are least attracted to the facilities (4.00). For Mall B customers above 40 years are more attracted to facilities in the mall (4.30) while customers between the ages of 31 and 40 years are least attracted to the facilities in the mall (3.64). For Mall C, customers within the age limit of 31-40 years are mostly attracted to facilities in the mall (4.08) while customers above the age of 40 years are least attracted to facilities in the mall (3.71). Customers less than 21 years are mostly attracted to the facilities in Mall D (4.33) while customers below 40 years are least attracted to the facilities in the mall (3.67). Mall $\mathrm{E}$ showed that customers within the ages of limit of 21-30 years are mostly attracted to facilities in the mall (3.98) while customers below 21 years are least attracted to facilities in the mall (3.50). Generally, a study of the entire shopping malls reveals that although majority of the shoppers are within the age bracket of 21 and 30 years (182), those within the age bracket of between 31 and 40 years are mostly attracted to the facilities in the malls (4.04). The age bracket of above 40years are however least attracted to the facilities in the malls (3.86). This perhaps is due to the fact that majority of customers within this age bracket could be nursing mothers or fathers that will take advantage of the facilities for their toddlers. Table 4 however, does not give any picture of attraction to the facilities reducing or increasing with age. Hence, it can be stated that the attraction to facilities in the mall has nothing to do with the age of customers. The Chi-Square test of significance is employed to ascertain if the result gotten is significant. Table 5 gives the graphic details:

Table 5: Chi-Square Table of Significance on Age

\begin{tabular}{|l|l|l|l|l|l|l|}
\hline Age(yrs) & $\begin{array}{l}\text { Well } \\
\text { attracted }\end{array}$ & attracted & indifferent & $\begin{array}{l}\text { Not } \\
\text { attracted }\end{array}$ & $\begin{array}{l}\text { No } \\
\text { response }\end{array}$ & Row sub-total \\
\hline$<\mathbf{2 1}$ & $46(46.10)$ & $20(22.72)$ & $16(13.76)$ & $8(6.12)$ & $7(8.30)$ & $\mathbf{9 7}$ \\
\hline $\mathbf{2 1 - 3 0}$ & $83(86.49)$ & $44(42.63)$ & $31(25.82)$ & $7(11.48)$ & $17(15.58)$ & $\mathbf{1 8 2}$ \\
\hline $\mathbf{3 1 - 4 0}$ & $58(54.65)$ & $30(26.94)$ & $10(16.32)$ & $8(7.52)$ & $9(9.84)$ & $\mathbf{1 1 5}$ \\
\hline$>\mathbf{4 0}$ & $24(23.76)$ & $10(11.71)$ & $6(7.09)$ & $5(3.15)$ & $5(4.28)$ & $\mathbf{5 0}$ \\
\hline $\begin{array}{l}\text { Column } \\
\text { sub-total }\end{array}$ & $\mathbf{2 1 1}$ & $\mathbf{1 0 4}$ & $\mathbf{6 3}$ & $\mathbf{2 8}$ & $\mathbf{3 8}$ & $\mathbf{4 4 4}$ \\
\hline
\end{tabular}


The Chi-Square test for each of the cells is deduced as follows: 0.0002; 0.3256;0.3647; 0.5775;0.2036;0.1408;0.0440;1.0392;1.7483;0.1294;0.2054;0.3476; 2.4475;0.0306;0.0717;0.0024;0.2497;

$0.1676 ; 1.0865 ; 0.1211$.This gives $\sum$ of 9.3031 . A (df) of 12 on the statistical table gives a value of 21.026. Since Cal $\vee_{2}<\mathrm{Tab}$ Cal $\vee 2$, the decision rule stipulates no significant difference in the result derived earlier. The difference could be as a result of chance. Thus, there are no significant difference amongst the various ages in its attraction to facilities in shopping malls.

\section{Marital Status on Attraction to Facilities}

The attraction of facilities in conjunction with the marital status of the respondents was sought. Details are as presented in Table 6

Table 6: Marital Status Attraction to Facilities of Malls

\begin{tabular}{|c|c|c|c|c|c|c|c|c|}
\hline & Marital & No. of & Well & attracted & indifferent & Not & No & Weighted \\
\hline SM & Status & respondents & attracted & & & attracted & response & Mean \\
\hline \multirow[t]{4}{*}{ A } & Single & 35 & 13 & 9 & 5 & 2 & 6 & 3.6 \\
\hline & Married & 49 & 26 & 11 & 7 & 4 & 1 & 4.16 \\
\hline & Divorced & 3 & 0 & 1 & 2 & 0 & 0 & 3.33 \\
\hline & Widow(er) & 0 & 0 & 0 & 0 & 0 & 0 & 0 \\
\hline \multirow[t]{4}{*}{ B } & Single & 58 & 28 & 16 & 8 & 2 & 4 & 4.07 \\
\hline & Married & 37 & 25 & 6 & 1 & 2 & 3 & 4.29 \\
\hline & Divorced & 1 & 1 & 0 & 0 & 0 & 0 & 5 \\
\hline & Widow(er) & 1 & 0 & 0 & 1 & 0 & 0 & 3 \\
\hline \multirow[t]{4}{*}{$\mathrm{C}$} & Single & 25 & 14 & 5 & 2 & 1 & 3 & 4.04 \\
\hline & Married & 56 & 31 & 9 & 12 & 4 & 0 & 4.2 \\
\hline & Divorced & 0 & 0 & 0 & 0 & 0 & 0 & 0 \\
\hline & Widow(er) & 2 & 0 & 1 & 1 & 0 & 0 & 3.5 \\
\hline \multirow[t]{4}{*}{ D } & Single & 26 & 11 & 12 & 3 & 0 & 0 & 4.31 \\
\hline & Married & 64 & 34 & 13 & 6 & 5 & 6 & 4 \\
\hline & Divorced & 2 & 1 & 0 & 1 & 0 & 0 & 4 \\
\hline & Widow(er) & 0 & 0 & 0 & 0 & 0 & 0 & 0 \\
\hline \multirow[t]{4}{*}{$\mathrm{E}$} & Single & 51 & 36 & 5 & 3 & 4 & 3 & 4.31 \\
\hline & Married & 28 & 14 & 10 & 2 & 0 & 2 & 4.21 \\
\hline & Divorced & 4 & 2 & 1 & 0 & 0 & 1 & 3.75 \\
\hline & Widow(er) & 2 & 0 & 1 & 1 & 0 & 0 & 3.5 \\
\hline \multirow[t]{4}{*}{ Total } & Single & 195 & 102 & 47 & 21 & 9 & 16 & 4.08 \\
\hline & Married & 234 & 130 & 49 & 28 & 15 & 12 & 4.15 \\
\hline & Divorced & 10 & 4 & 2 & 3 & $\mathbf{0}$ & 1 & 3.5 \\
\hline & Widow(er) & 5 & $\mathbf{0}$ & 2 & 3 & $\mathbf{0}$ & 0 & 2.8 \\
\hline
\end{tabular}

As revealed from Table 6, most of the malls are visited by married persons (Mall A, C, and D) while the other two malls are visited more by singles. The table further shows that no specific marital status can be said to be attracted the most from the various malls. For instance in Mall A the married are more attracted to facilities in the mall (4.16). In Mall B, also the married tend to be attracted more to the facilities in the mall (4.29). This is however not considering the outliner of divorced persons who is only one of the respondent studied in the mall with a weighted average of (5.00).

In Mall C, the married are more prone to be attracted to facilities in the mall (4.20). In Mall D, the singles have greater propensity to be attracted by the facilities in the mall (4.31).

This is also the same situation in Mall E where the singles also liable to be attracted by facilities in the Mall. When the malls were all studied collectively the weighted mean gotten for each marital status indicates that those married had the biggest weighted mean

(4.15). However the presence of the outliners of both those divorced and the widow or widowers. The result was tested with the Chi-Square test of significance for any significance in the result gotten. Table 7 gives the graphic details of the Chi-Square result 
Table 7: Chi-Square Table of Significance on Marital status

\begin{tabular}{|l|l|l|l|l|l|l|}
\hline $\begin{array}{l}\text { Marital } \\
\text { Status }\end{array}$ & $\begin{array}{l}\text { Well } \\
\text { attracted }\end{array}$ & attracted & indifferent & $\begin{array}{l}\text { Not } \\
\text { attracted }\end{array}$ & $\begin{array}{l}\text { No } \\
\text { response }\end{array}$ & Row sub-total \\
\hline Single & $102(103.65)$ & $47(43.92)$ & $21(24.16)$ & $9(10.54)$ & $16(12.74)$ & $\mathbf{1 9 5}$ \\
\hline Married & $130(124.38)$ & $49(52.70)$ & $28(28.99)$ & $15(12.65)$ & $12(15.28)$ & $\mathbf{2 3 4}$ \\
\hline Divorced & $4(5.32)$ & $2(2.25)$ & $3(1.24)$ & $0(0.54)$ & $1(0.65)$ & $\mathbf{1 0}$ \\
\hline Widow(er) & $0(2.66)$ & $2(1.13)$ & $3(0.62)$ & $0(0.27)$ & $0(0.33)$ & $\mathbf{5}$ \\
\hline $\begin{array}{l}\text { Column } \\
\text { sub-total }\end{array}$ & $\mathbf{2 3 6}$ & $\mathbf{1 0 0}$ & $\mathbf{5 5}$ & $\mathbf{2 4}$ & $\mathbf{2 9}$ & $\mathbf{4 4 4}$ \\
\hline
\end{tabular}

Analysis using the Chi-Square test of significance gives the various values for each cell: $0.0263 ; 0.2160 ; 0.4133$; $0.2250 ; 0.8342 ; 0.2539 ; 0.2598 ; 0.0338 ; 0.4366 ; 0.7041 ; 0.3275 ; 0.0278 ; 2.4981 ; 0.54 ; 0.1884 ; 2.66$;

$0.6698 ; 9.136 ; 0.27 ; 0.33$. This gives $\sum$ of 20.0506 .

A (df) of 12 on the statistical table gives a value of 21.026. Since Cal $\vee_{2}<$ Tab Cal $\vee_{2}$, the decision rule stipulates no significant difference in the result derived earlier. The difference could be as a result of chance. Thus, there are no significant difference amongst the various marital status in its attraction to facilities in shopping malls.

\section{Income Level on Attraction to Facilities}

The level of income of the customers to the various malls were also studied in order to discover if any significant difference exists amongst the various income level and attraction of customers to the facilities provided in the mall. Table 8 gives more details.

Table 8: Income Level Attraction to Facilities of Malls

\begin{tabular}{|c|c|c|c|c|c|c|c|c|}
\hline SM & $\begin{array}{l}\text { Monthly } \\
\text { Income } \\
\text { (N'000) }\end{array}$ & $\begin{array}{l}\text { No. of } \\
\text { respondents }\end{array}$ & $\begin{array}{l}\text { Well } \\
\text { attracted }\end{array}$ & attracted & indifferent & $\begin{array}{l}\text { Not } \\
\text { attracted }\end{array}$ & $\begin{array}{l}\text { No } \\
\text { response }\end{array}$ & $\begin{array}{l}\text { Weighted } \\
\text { Mean }\end{array}$ \\
\hline \multirow[t]{5}{*}{$\bar{A}$} & $<30$ & 38 & 13 & 10 & 5 & 3 & 7 & 3.50 \\
\hline & $30-50$ & 17 & 6 & 5 & 3 & 2 & 1 & 3.76 \\
\hline & $>50<100$ & 12 & 7 & 2 & 1 & 1 & 1 & 4.08 \\
\hline & $>100<150$ & 11 & 5 & 3 & 1 & 0 & 2 & 3.82 \\
\hline & $>150$ & 9 & 6 & 2 & 0 & 0 & 1 & 4.33 \\
\hline \multirow[t]{5}{*}{ B } & $<30$ & 29 & 10 & 8 & 7 & 4 & 0 & 3.83 \\
\hline & $30-50$ & 26 & 14 & 3 & 5 & 3 & 1 & 4.00 \\
\hline & $>50<100$ & 18 & 11 & 5 & 1 & 0 & 1 & 4.38 \\
\hline & $>100<150$ & 4 & 1 & 2 & 0 & 1 & 0 & 3,75 \\
\hline & $>150$ & 20 & 12 & 5 & 3 & 0 & 0 & 4.45 \\
\hline \multirow[t]{5}{*}{$\bar{C}$} & $<<30$ & 16 & 8 & 3 & 2 & 2 & 1 & 3.94 \\
\hline & $30-50$ & 34 & 16 & 11 & 3 & 2 & 2 & 4.09 \\
\hline & $>50<100$ & 13 & 8 & 4 & 1 & 0 & 0 & 4.54 \\
\hline & $>100<150$ & 11 & 7 & 2 & 0 & 2 & 0 & 4.27 \\
\hline & $>150$ & 9 & 4 & 3 & 1 & 1 & 0 & 4.11 \\
\hline \multirow[t]{5}{*}{$\bar{D}$} & $<30$ & 25 & 10 & 6 & 2 & 3 & 4 & 3.60 \\
\hline & $30-50$ & 46 & 22 & 9 & 6 & 4 & 5 & 3.85 \\
\hline & $>50<100$ & 11 & 5 & 3 & 2 & 0 & 1 & 4.00 \\
\hline & $>100<150$ & 6 & 4 & 2 & 0 & 0 & 0 & 4.66 \\
\hline & $>150$ & 4 & 3 & 1 & 0 & 0 & 0 & 4.75 \\
\hline \multirow[t]{5}{*}{$\mathrm{E}$} & $<30$ & 26 & 11 & 11 & 4 & 0 & 0 & 4.27 \\
\hline & $30-50$ & 26 & 13 & 8 & 2 & 2 & 1 & 4.15 \\
\hline & $>50<100$ & 17 & 9 & 4 & 3 & 1 & 0 & 4.24 \\
\hline & $>100<150$ & 10 & 6 & 1 & 2 & 0 & 1 & 4.10 \\
\hline & $>150$ & 6 & 3 & 2 & 0 & 1 & 0 & 4.17 \\
\hline \multirow[t]{5}{*}{ Total } & $<30$ & 134 & 52 & 38 & 20 & 12 & 12 & 3.79 \\
\hline & $30-50$ & 149 & 71 & 36 & 19 & 13 & 10 & 3.97 \\
\hline & $>50<100$ & 71 & 40 & 18 & 8 & 2 & 3 & 4.30 \\
\hline & $>100<150$ & 42 & 23 & 10 & 3 & 3 & 3 & 4.12 \\
\hline & $>150$ & 48 & 28 & 13 & 4 & 2 & 1 & 4.35 \\
\hline
\end{tabular}

As revealed from Table 8 , most of the respondents are on the lower income cadre. This could be because the town itself is a town mainly comprised of civil servants and students due to the presence of some citadel of learning. This is contrary to what might be expected in more industrialize cities like Lagos. It was also observed that the higher income earners were more prone to be attracted to the facilities in the shopping malls, however with certain exceptions. For Mall D the progression in the attraction of facilities in the mall was on an ascending order of income 
level. For Mall A, and Mall B the progression was truncated at the income level of $>$ N100, 000 <N150, 000. For Mall $\mathrm{C}$ the progression was truncated at the income level of $>\mathrm{N} 100,000<\mathrm{N} 150,000$ and those $>\mathrm{N} 150$, 000 . The progression in Mall E cannot be said to be regular. Hence, from Table 8 the following observations are made. Those who earn $>$ N150, 000 are mostly attracted to the facilities in the mall (4.33) while those who earn $<\mathrm{N} 30$, 000 are least attracted to facilities in the mall (3.50). The situation is a bit different in Mall B where those who earn $>\mathrm{N} 150$, 000 are mostly attracted to the facilities in the mall (4.45) while those who earn $>\mathrm{N} 100,000<\mathrm{N} 150,000$ are least attracted to facilities in the mall (3.75). For Mall $\mathrm{C}$ those mostly attracted to the facilities in the mall are those within the monthly income of $>\mathrm{N} 50,000<\mathrm{N} 100,000$ (4.54) whereas the least attracted to facilities in the mall are those within the income level of <N30, 000 (3.94). In Mall D those within the income level of $>$ N150, 000 are mostly attracted to facilities in the mall (4.75) while those within the income level of $<\mathrm{N} 30,000$ are the least attracted to facilities in the mall. In Mall E, those within the income level of $<\mathrm{N} 30,000$ are the most attracted to facilities in the mall (4.27) while those within the income level of $>\mathrm{N} 100,000<\mathrm{N} 150,000$ are the least attracted to facilities in the mall (4.10). This divergent result gotten from the various malls will therefore require the analysis of the collective malls. The result indicates that the higher the income of the customers the more attracted they are to facilities in the malls. However, those within the income bracket of $>\mathrm{N} 100,000<\mathrm{N} 150,000$ truncated the proposition as revealed in Table 8. Generally those that earn $>$ N150, 000 are mostly attracted to facilities in the malls (4.35) while those that earn $<\mathrm{N} 30,000$ are least attracted to facilities in the malls (3.79). In order to confirm the significance of these results a Chi-Square test of significance was also utilized. Table 9 gives the graphic details

Table 9: Chi-Square Table of Significance on Income Level

\begin{tabular}{|l|l|l|l|l|l|l|}
\hline $\begin{array}{l}\text { Monthly Income } \\
\text { (A, 000) }\end{array}$ & Well attracted & attracted & indifferent & Not attracted & No response & Row sub-total \\
\hline$<30$ & $52(64.59)$ & $38(34.70)$ & $20(16.30)$ & $12(9.66)$ & $12(8.75)$ & $\mathbf{1 3 4}$ \\
\hline $30-50$ & $71(71.82)$ & $36(38.59)$ & $19(18.12)$ & $13(10.74)$ & $10(9.73)$ & $\mathbf{1 4 9}$ \\
\hline$>50<100$ & $40(34.22)$ & $18(18.39)$ & $8(8.64)$ & $2(5.12)$ & $3(4.64)$ & $\mathbf{7 1}$ \\
\hline$>100<150$ & $23(20.24)$ & $10(10.88)$ & $3(5.11)$ & $3(3.03)$ & $3(2.74)$ & $\mathbf{4 2}$ \\
\hline$>150$ & $28(23.14)$ & $13(12.43)$ & $4(5.84)$ & $2(3.46)$ & $1(3.14)$ & $\mathbf{4 8}$ \\
\hline $\begin{array}{l}\text { Column } \\
\text { sub-total }\end{array}$ & $\mathbf{2 1 4}$ & $\mathbf{1 1 5}$ & $\mathbf{5 4}$ & $\mathbf{3 2}$ & $\mathbf{2 9}$ & $\mathbf{4 4 4}$ \\
\hline
\end{tabular}

The use of the Chi-Square test of significance resulted in the various values for each cell: $2.4541 ; 0.3138$; $0.8399 ; 0.5668 ; 1.2071 ; 0.0094 ; 0.1738 ; 0.0427 ; 0.4756 ; 0.0075 ; 0.9763 ; 0.0083 ; 0.0474 ; 1.9013$;

$$
0.5797 ; 0.3764 ; 0.0712 ; 0.8713 ; 0.0003 ; 0.0247 ; 1.0207 ; 0.0261 ; 0.5797 ; 0.6161 ; 1.4585 \text {. This gives } \sum \text { of }
$$

14.6487. A (df) of 16 on the statistical table gives a value of 26.296 . Since Cal $\vee 2<\mathrm{Tab}$ Cal $\vee 2$, the decision rule stipulates no significant difference in the result derived earlier. This could also be as a result of chance. This implies that the income level of the respondents makes no difference in attracting customers to the facilities provided in the malls.

\section{Conclusion}

This study has been able to discover the attraction of certain demographic features of customers to the facilities provided in shopping malls in the study area, Ibadan, Nigeria. It was discovered that only gender was a determining factor as females tend to be attracted more to facilities provided in shopping malls than their male counterparts. The inference from this findings will give various stakeholders a stronghold in relating to issues pertaining to facilities of shopping malls. It is a good ground for determining the benchmark for facilities provision that must be adhered to by all shopping mall operators while further research can be conducted on various other demographic features attracting customers to facilities provided in shopping malls. However, the researchers hereby opine that building of this retail shopping outfit which has become in vogue should be gender sensitive. Facilities should be enhanced to cater for the peculiarity of the female folks as that will not only increase their visitation but also patronage of the malls.

\section{Acknowledgement}

The authors hereby acknowledge Covenant University, Ota for the sponsorship of this research work

\section{References}

[1] Abrudan, I. N. (2016). Influence Factors for Store Format Choice in the Apparel and Footwear Market. Management and Marketing, 14(1), 79-90 
[2] alAfeef, M., Singh, D., \& Ahmad, K. (2012). The Influence of Demographic Factors and User Interface on Mobile Banking Adoption: A Review. Journal of applied sciences, 12(20), 2082-2095.

[3] Anderson, J. G. (1973). Demographic factors affecting health services utilization: a causal model. Medical Care, 104-120.

[4] Bailey, M. (2015). Shopping for entertainment: malls and multiplexes in Sydney, Australia. Urban History, 42(2), 309-329.

[5] Berlemann, M., Oestmann, M., \&Thum, M. (2014). Demographic change and bank profitability: empirical evidence from German savings banks. Applied Economics, 46(1), 79-94.

[6] Bhatti, K., and Latif, S. (2014). The Impact of Visual Merchandising on Consumer Impulse Buying Behavior. Eurasian Journal of Business and Management, 2(1), 24-35

[7] Biernat, E., \&Tomaszewski, P. (2011). Socio-demographic and leisure activity determinants of physical activity of working Warsaw residents aged 60 to 69 years. Journal of human kinetics, 30, 173-181.

[8] Bloom, D. E., McKenna, M., \&Prettner, K. (2018). Demography, unemployment, automation, and digitalization: Implications for the creation of (decent) jobs, 2010-2030 (No. w24835). National Bureau of Economic Research.

[9] Bustam, T. D., Thapa, B., \&Buta, N. (2011). Demographic Differences within Race/Ethnicity Group Constraints to Outdoor Recreation Participation. Journal of Park \& Recreation Administration, 29(4), 5371

[10] Carpenter, J. M. (2008). Demographics and patronage motives of supercenter shoppers in the United State. International Journal of Retail \& Distribution Management, 36(1)5- 16

[11] Child, S., Kaczynski, A. T., Sharpe, P. A., Wilcox, S., Schoffman, D. E., Forthofer, M., Mowen, A. J. and Barr-Anderson, D. J. (2015). Demographic differences in perceptions of outdoor recreation areas across a decade. Journal of Park and Recreation Administration, 33(2), 1- 19

[12] Dodge, Y. (2006). The Oxford Dictionary of Statistical Terms. Oxford, UK: Oxford University Press

[13] Doerr, S., \&Kabas, G. (2019). Banking On Demography: Population Aging and Financial Integration. Available at SSRN3430184. : https://ssrn.com/abstract=3430184 or http://dx.doi.org/10.2139/ssrn.3430184 retrieved on November 30, 2019

[14] Dubihlela, D. (2014). Attributes of Shopping Mall Image, Customer Satisfaction and Mall Patronage for Selected Shopping Malls in Southern Gauteng, South Africa. Journal of Economics and Behavioral Studies, 6(8), 682-689

[15] Eime, R.M., Harvey, J.T., Charity, M.J. and Nelson, R. (2018). Demographic characteristics and type/frequency of physical activity participation in a large sample of 21,603 Australian people. BMC Public Health 18, 692 (2018) doi:10.1186/s12889-018-5608-1

[16] Fotso, J. C., Bellhouse, L., Vesel, L., \&Jezman, Z. (2015). Strengthening the home-to-facility continuum of newborn and child health care through mHealth: Evidence from an intervention in rural Malawi. African Population Studies, 29(1), 1663-1682.

[17] Graham, B. (2018). Population characteristics and geographic coverage of primary care facilities. BMC health services research, 18(1), 398.

[18] Guile, L., Graham, D., \&Jachmann, A. (2018). Health and Demographic Characteristics of Patients Attending a Newly-Opened Medical Facility in a Remote Amazonian Community: A Descriptive Study. Medical Sciences, 6(4), 106.

[19] Gupta, S. and Gupta, T. (2017). Involvement with experience: A path to brand loyalty. IMJ, 9 (2), 1-16.

[20] Hassan, Y., Muhammad, N. M. N., and Bakar, H. A. (2010). Influence of Shopping Orientation and store image on patronage of furniture stores. International Journal of Marketing Studies, 2(1), 175- 184

[21] Hira, F., and Mehvish, R. (2012). Determining the Factors affecting Consumer Loyalty towards Shopping Malls. Global Advanced Research Journal of Management and Business Studies, 1(4) 134- 140

[22] Idoko, E. C., Ukenna, S. I., \&Obeta, C. E. (2019). Determinants of shopping mall patronage frequency in a developing economy: Evidence from Nigerian mall shoppers. Journal of Retailing and Consumer Services, 48, 186-201.

[23] Iroham, C. O., Durodola, O. D., Oluwatobi, A. O. and Peter, N. J. (2015). A search for application level of heuristics in property valuation in three Nigerian Cities. Proceedings of the 25th International Business Information Management Association Conference- Innovation Vision 2020: From Regional Development Sustainability to Global Economic Growth, IBIMA 2015, 3756-3763

[24] Jones, G. W. (1976). The influence of demographic variables on development via their impact on education. In Economic Factors in Population Growth (pp. 553-593). Palgrave Macmillan, London 
[25] Joshi, K. K. and Gupta, S. (2017). Factors affecting performance of a shopping mall. IOSR Journal of Business and Management (IOSR-JBM), 19(12), 1-14

[26] Juhari, N. H., Ali, H. M., \&Khair, N. (2012). The shopping mall services cape affects customer satisfaction. In 3rd international conference on business and economic research, 617-632.

[27] Kedhi, K. El., Zourrig, H. and Park, J. (2017). Image transfer from malls to stores and its influence on shopping values and mall patronage: The role of self-congruity. Journal of Retailing and Consumer Services, 39, 208-218

[28] Khare, A. (2012). Influence of mall attribute and demographics on Indian consumers' mall involvement behavior: An explorative study. Journal of Targeting, Measurement and Analysis 20 (3-4) 192-202

[29] Lutz, W., Cuaresma, J. C., Kebede, E., Prskawetz, A., Sanderson, W. C., \&Striessnig, E. (2019). Education rather than age structure brings demographic dividend. Proceedings of the National Academy of Sciences, 116(26), 12798-12803.

[30] Malik, N. S., and Ali Syed, A. (2013). Buyer's Behavior in Organized Retail: An Exploratory Study. International Journal of Research in Commerce \& Management, 4(4), 87-93

[31] Mittal, A., and Jhamb, D. (2016). Determinants of Shopping Mall Attractiveness: The Indian Context, Procedia Economics and Finance 37, 386 - 390

[32] Mokgabudi, L. R. (2011). The impact of shopping mall developments on consumer behaviour in township area (Unpublished M.Sc Dissertation) Department of Business Administration, University of Pretoria, South Africa

[33] Monisha, A. N., Divyalakshmi, S., \&Dhivyaa, M. (2019). The Conceptual Understanding of "Why Malls Are Not Preferred By South Indians". IOSR Journal of Business and Management (IOSR-JBM), 21(4), 5458.

[34] Nayyab, H. H., Sehr, A., Adnan, M., \& Ali, Z. (2011). Impact of customer demographic on bank Selection criteria: A study of banking sector of Okara, Punjab (Pakistan). Interdisciplinary Journal of contemporary Research In Business, 3(2), 773-789

[35] Nelson, A. E., Howe, C. J., Nguyen, T. V., Leung, K. C., Trout, G. J., Seibel, M. J., Baxter, R.C., Handelsman, D. J., Kazlauskas, R. and Ho, K. K. (2006). Influence of demographic factors and sport type on growth hormone-responsive markers in elite athletes. The Journal of Clinical Endocrinology \& Metabolism, 91(11), 4424-4432.

[36] Ngangu, P. T., (2016). The demography and current work conditions of Cameroonian professional journalists. In Proceedings of the 2nd World Conference on Media and Mass Communication, 1, 42-51).

[37] Okoro, D. P., Okolo, V. O., and Mmamel, Z. U. (2019). Determinants of Shopping Mall

[38] Patronage among Consumers in Enugu Metropolis. International Journal of Academic Research in Business and Social Sciences, 9(11), 400-420.

[39] Peter, N. J., Ayedun, C. A., and Iroham, C. O. (2018). Registration into associate membership status of the Nigerian institution of estate surveyors and valuers (NIESV): The challenges. International Journal of Civil Engineering and Technology, 9(10), 1239-1251

[40] Poovalingam, K., and Docrat, S. (2011). Consumer decision-making in the selection of shopping centres around Durban. Management, Informatics and Research Design, 18(1), 215-251.

[41] Prashar, S., Singh, H., Parsad, C., \& Vijay, T. S. (2017). Predicting Indian shoppers' malls loyalty behaviour. Vikalpa, 42(4), 234-250.

[42] Rabbanee, F. K., Ramaseshan, B., Wu, C. and Vinden, A. (2012). Effects of store loyalty on shopping mall loyalty, Journal of Retailing and Consumer Services, 19(3), 271-278

[43] Reikli, M. (2012). The key of success in shopping centres: Composing elements of shopping centres and their strategic fit. (Unpublished Ph.D Thesis), Corvinus University of Budapest

[44] Sohail, M. S. (2015). Gender differences in mall shopping: a study of shopping behaviour

[45] of an emerging nation. Journal of Marketing and Consumer Behaviour in Emerging Markets, 1(1), 36- 46.

[46] Solomon, E. S. (2007). Analysis of the demographic characteristics of pediatric dental practice sites. Pediatric dentistry, 29(3), 214-219.

[47] VanderStel, A. (2014). The Impact of Demographics in Education. Honors Projects. 329

[48] Wong, S., Siu, V., \& Tsang, N. (1999). The impact of demographic factors on Hong Kong hotel employees' choice of job-related motivators. International Journal of Contemporary Hospitality Management, 11(5), 230-242. 